\title{
PENGARUH MODEL PEMBELAJARAN DAN KONSEP DIRI TERHADAP HASIL BELAJAR IPA
}

\begin{abstract}
Agus Jatmiko
Universitas Islam Negeri Raden Intan Lampung. Jl. H Endro Suratmin SukarameBandar Lampung (0721) 70326: ajatmiko62@yahoo.co.id

Diterima : 07 Agustus 2017. Disetujui: 15 Desember 2017. Dipublikasikan: 29 Desember 2017

Abstract. This research was intended to reveal the effect of instructional model and selfconcept on learning achievement of Science. The research use experimental method with $2 X 2$ factorial design and was carried out at SMP Negeri 24 Bandar Lampung with sample of 44 students. ANAVA applied to analyzed the data obtained at the significant level of 0,05.The results of this research are: (1) student's learning achievement of Science who uses by Learning Cycle model is higher than Contextual Teaching and Learning model; (2) There is an interaction effect between instructional model and selfconcept on student's learning achievement of Science; (3) student's learning achievement of Science who uses by Learning Cycle model is higher than Contextual Teaching and Learning model with positive self-concept; 4) student's learning achievement of Science who uses by Learning Cycle model is lower than Contextual Teaching and Learning model with negative self-concept.
\end{abstract}

Keywords: Learning Cycle, Contextual Teaching and Learning, Self-concept, Learning Achievement of Science.

Abstrak: Tujuan penelitian ini adalah untuk mengetahui pengaruh model pembelajaran dan konsep diri terhadap hasil belajar IPA. Penelitian eksperimen ini dilakukan di SMP Negeri 24 Bandar Lampung dengan rancangan faktorial 2x2. Dengan jumlah sampel 44 siswa. Analisis data menggunakan ANAVA dengan taraf signifikansi 0,05. Hasil penelitian ini adalah sebagai berikut: 1) hasil belajar IPA siswa yang menggunakan model Learning Cycle lebih tinggi daripada model Contextual Teaching and Learning; 2) ada pengaruh interaksi antara model pembelajaran dan konsep diri terhadap hasil belajar IPA; 3) pada kelompok yang memiliki konsep diri positif, hasil belajar IPA siswa yang belajar menggunakan model Learning Cycle lebih tinggi dari siswa yang belajar menggunakan model Contextual Teaching and Learning; dan 4) pada kelompok yang memiliki konsep diri negatif, hasil belajar IPA siswa yang belajar dengan model Learning Cycle lebih rendah dari siswa yang belajar dengan model Contextual Teaching and Learning.

Kata kunci: Learning Cycle, Contextual Teaching and Learning, Konsep Diri, Hasil Belajar IPA, 


\section{PENDAHULUAN}

Kurang keberhasilan pencapaian pembelajaran IPA disebabkan siswa kurang diperlakukan sebagai bagian dari realitas dunia dalam pembelajaran di kelas. Model pembelajaran konvensional di kelas masih dominan digunakan dimana pembelajaran IPA sebagian besar memanfatkan bahan ajar yang berupa buku teks dan lembar kerja siswa (LKS) yang wajib dimiliki setiap siswa. Sebagaimana yang diamanatkan pada mata pelajaran IPA, bahwa pembelajaran IPA sebaiknya dilaksanakan secara inkuiri ilmiah (BSNP, 2006: 149) yaitu pembelajaran yang dapat menumbuhkan kemampuan berpikir, bekerja dan bersikap ilmiah dengan pemberian pengalaman belajar secara langsung.

Model pembelajaran yang diduga sesuai dan dapat meningkatkan hasil belajar IPA adalah: Pertama, model Learning Cycle. Dugaan tersebut berakar dari fase-fase belajar yang ada pada model Learning Cycle (Carin, 1993: 87-88), yaitu (1) Exploration Phase (memberikan siswa memiliki pengalaman langsung berinteraksi dengan lingkungan alam); (2) Concept Introduction Phase (memungkinkan siswa membangun pemahaman konsep pengetahuan); (3) Concept Application Phase (mengharuskan siswa menerapkan pemahaman konsepnya pada situasi baru). Kedua, model Contextual Teaching and Learning, yakni model pembelajaran yang menekankan pada aktivitas siswa untuk belajar dengan mengedepankan keterkaitan materi yang diajarkan dengan keadaan kehidupan nyata siswa sehari-hari (Johnson, 2009: 64).

Selanjutnya, pembelajaran dengan model Learning Cycle diharapkan dapat memberikan perbedaan hasil belajar yang akan dilakukan dengan penelitian ekperimen yaitu dengan membandingkan rata-rata hasil belajar siswa pada pelajaran IPA dengan 
menggunakan model pembelajaran Contextual Teaching and Learning yang dilakukan secara bersamaan pada kelas yang berbeda.

Tujuan penelitian ini adalah untuk mengetahui:

1. Perbedaan hasil belajar IPA antara siswa yang menggunakan model pembelajaran Learning Cycle dengan model Contextual Teaching and Learning.

2. Pengaruh interaksi antara model pembelajaran dan konsep diri siswa terhadap hasil belajar IPA.

3. Perbedaan hasil belajar IPA antara siswa yang menggunakan model pembelajaran Learning Cycle dengan model pembelajaran Contextual Teaching and Learning pada siswa yang memiliki konsep diri positif.

4. Perbedaan hasil belajar IPA antara siswa yang menggunakan model pembelajaran Learning Cycle dengan model pembelajaran Contextual Teaching and Learning pada siswa yang memiliki konsep diri negatif.

\section{METODE}

Penelitian ini menggunakan metode eksperimen dengan disain treatment by level 2x2. Variabel penelitian terdiri dari satu variabel terikat, yaitu hasil belajar IPA dan dua variabel bebas, yaitu model pembelajaran sebagai variabel perlakuan serta konsep diri sebagai variabel atribut. Variabel model pembelajaran terdiri dari dua model, yaitu model pembelajaran Learning Cycle dan model pembelajaran Contextual Teacher and Learning, sedangkan variabel atribut konsep diri terbagi menjadi konsep diri positif dan konsep diri negatif. Desain eksperimen penelitian disajikan dalam bentuk kontelasi penelitian sehingga dapat memberikan gambaran untuk menguji efektivitas perlakuan 
dalam eksperimen. Selanjutnya, konstelasi penelitian dapat ditunjukkan pada Tabel 1 berikut ini

Tabel 1.

Rancangan Eksperimen (Disain Treatment by Level 2X2)

\begin{tabular}{cccc}
\hline & & \multicolumn{2}{c}{$\begin{array}{c}\text { Variabel Perlakuan } \\
(\mathrm{A})\end{array}$} \\
\cline { 2 - 4 } Variabel Atribut & $\begin{array}{c}\text { Model } \\
\text { Learning Cycle } \\
\left(\mathrm{A}_{1}\right)\end{array}$ & $\begin{array}{c}\text { Model } \\
\text { Contextual Teacher } \\
\text { and Learning }\left(\mathrm{A}_{2}\right)\end{array}$ \\
\hline \multirow{2}{*}{$\begin{array}{c}\text { Konsep diri } \\
(\mathrm{B})\end{array}$} & $\begin{array}{c}\text { Konsep diri } \\
\text { positif } \\
\left(\mathrm{B}_{1}\right)\end{array}$ & $\left(\mathrm{A}_{1} \mathrm{~B}_{1}\right)$ & $\left(\mathrm{A}_{2} \mathrm{~B}_{1}\right)$ \\
\cline { 2 - 4 } & $\begin{array}{c}\text { Konsep diri } \\
\text { negaitif } \\
\left(\mathrm{B}_{2}\right)\end{array}$ & $\left(\mathrm{A}_{1} \mathrm{~B}_{2}\right)$ & $\left(\mathrm{A}_{2} \mathrm{~B}_{2}\right)$ \\
\hline
\end{tabular}

Keterangan:

$\mathrm{A}_{1} \mathrm{~B}_{1}$ : ompok siswa yang menggunakan model Learning Cycle yang memiliki konsep diri positif

$\mathrm{A}_{2} \mathrm{~B}_{1}$ : Kelompok siswa yang menggunakan model Contextual Teacher and Learning yang memiliki konsep diri positif

$\mathrm{A}_{1} \mathrm{~B}_{2}$ : Kelompok siswa yang menggunakan model Learning Cycle yang memiliki konsep diri negatif

$\mathrm{A}_{2} \mathrm{~B}_{2}$ : Kelompok siswa yang menggunakan model Contextual Teacher and Learning yang memiliki konsep diri negatif

Populasi target dalam penelitian ini adalah seluruh siswa SMP Negeri 24 Bandar Lampung. Sebagai sampel penelitian ini adalah 72 siswa dari dua kelas yang berbeda. Teknik pengambilan sampel dilakukan secara multistage random sampling. (1) Menetapkan kelas VIII sebagai responden secara purposive sampling, dengan asumsi bahwa siswa kelas VII baru memulai pembelajaran dan siswa kelas IX dalam kondisi persiapan untuk menghadapi ujian akhir nasional (UN); (2) Mengambil dua kelas secara random dengan asumsi dua kelas tersebut secara rata-rata memiliki karakteristik siswa 
yang hampir sama dalam hal prestasi akademik, keaktifan belajar, dan jumlah siswa tiap kelas; (3) Setelah terpilih dua kelas, selanjutnya mengundi dua kelas tersebut untuk menentukan kelas yang akan diberi perlakuan model pembelajaran; (3) Hasil pengundian diperoleh kelas VIII E sebagai kelas eksperimen yang akan menerima pembelajaran menggunakan model Learning Cycle, dan kelas $\mathrm{VIII}^{\mathrm{F}}$ sebagai kelas kontrol yang akan menerima pembelajaran menggunakan model Contextual Teacher and Learning; (4) Siswa yang terpilih sebagai sampel selanjutnya diberi kuesioner tentang konsep diri. Skor kuesioner diurutkan dari tertinggi ke terendah, diambil $30 \%$ siswa kelompok atas dari 36 siswa, dan diambil 30\% siswa kelompok bawah dari 36 siswa (Naga, 2008: 83) Sehingga total sampel berjumlah 44 dengan distribusi pada tiap sel 11 siswa. Mengenai pengelompokan sampel penelitian dapat dilihat pada Tabel 2 berikut ini.

Tabel 2. Komposisi Subjek Penelitian

\begin{tabular}{rrc}
\hline Konsep & \multicolumn{2}{c}{ Model Pembelajaran } \\
\cline { 2 - 3 } diri & $\begin{array}{r}\text { Learning } \\
\text { Cycle }\end{array}$ & $\begin{array}{c}\text { Contextual Teacher and } \\
\text { Learning }\end{array}$ \\
\hline Positif & 11 siswa & 11 siswa \\
\hline Negatif & 11 siswa & 11 siswa \\
\hline Jumlah & 22 siswa & 22 siswa \\
\hline
\end{tabular}

Instrumen yang digunakan untuk mengumpulkan data penelitian ini, berbentuk tes dan kuesioner. Tes dalam bentuk pilihan ganda digunakan untuk mengumpulkan data hasil belajar IPA. Sementara kuesioner berbentuk skala skala likert dengan lima pilihan jawaban $(5=$ sangat sesuai, $4=$ sesuai, $3=$ kurang sesuai, $2=$ tidak sesuai, dan 1 = sangat tidak sesuai untuk pernyataan positif, dan sebaliknya untuk pernyataan negatif) digunakan untuk memperoleh data konsep diri. 
Teknik analisis data yang digunakan adalah teknik analisis varians (ANAVA) dua jalan, yang dilanjutkan dengan uji Tukey (Murwani: 2005, 62-63). Sebelum dilakukan analisis dengan ANAVA dua jalan terlebih dahulu dilakukan uji persyaratan meliputi (a) uji normalitas data dengan uji Lilliefors, uji homogenitas menggunakan uji Bartlett.

\section{HASIL}

Pada Tabel 3 berikut ini ditampilkan perbandingan hasil belajar IPA siswa yang menggunakan model Learning Cycle dan Model Contextual Teaching and Learning.

Tabel 3. Rekapitulasi Skor Hasil Belajar IPA pada Semua Kelompok Perlakuan Penelitian

\begin{tabular}{|c|c|c|c|c|}
\hline \multirow[b]{2}{*}{$\begin{array}{c}\text { Konsep Diri } \\
\text { (B) }\end{array}$} & \multirow[b]{2}{*}{ Keterangan } & \multicolumn{2}{|c|}{ Model Pembelajaran (A) } & \multirow[b]{2}{*}{ Total } \\
\hline & & $\begin{array}{c}\text { Learning Cycl } \\
\text { (A1) }\end{array}$ & $\begin{array}{c}\text { Contextual } \\
\text { Teaching and } \\
\text { Learning }\left(\mathrm{A}_{2}\right)\end{array}$ & \\
\hline \multirow{5}{*}{$\begin{array}{l}\text { Konsep } \\
\text { Diri Positif } \\
\quad\left(\mathrm{B}_{1}\right)\end{array}$} & $\mathrm{N}$ & 11 & 11 & 22 \\
\hline & Mean & 34,73 & 24,27 & 29,5 \\
\hline & Std. Dev & 3,63 & 4,03 & 6,35 \\
\hline & Minimum & 31 & 20 & 20 \\
\hline & Maksimum & 40 & 30 & 40 \\
\hline \multirow{5}{*}{$\begin{array}{c}\text { Konsep } \\
\text { Diri } \\
\text { Negatif } \\
\left(\mathrm{B}_{2}\right) \\
\end{array}$} & $\mathrm{N}$ & 11 & 11 & 22 \\
\hline & Mean & 14,18 & 18,82 & 16,5 \\
\hline & Std. Dev & 3,76 & 5,71 & 5,28 \\
\hline & Minimum & 10 & 10 & 10 \\
\hline & Maksimum & 23 & 25 & 25 \\
\hline \multirow{5}{*}{ Total } & $\mathrm{N}$ & 22 & 22 & 44 \\
\hline & Mean & 24,45 & 21,55 & 23 \\
\hline & Std. Dev & 11,01 & 5,57 & 4,28 \\
\hline & Minimum & 10 & 10 & 10 \\
\hline & Maksimum & 40 & 30 & 40 \\
\hline
\end{tabular}

\section{Keterangan}

n : Jumlah sampel setiap kelompok

Teknik yang digunakan untuk menguji hipotesisi penelitian adalah analisis varians (ANAVA) dua jalan. Apabila hasil analisis data menunjukkan adanya pengaruh interaksi antara model pembelajaran dan konsep diri terhadap hasil belajar IPA, maka 
analisis dapat dilanjutkan dengan menggunakan Uji Tukey. Setelah dilakukan perhitungan diperoleh hasil seperti pada Tabel 4 berikut.

Tabel 4. Rangkuman Hasil ANAVA Pengaruh Model Pembelajaran dan Konsep Diri terhadap Hasil Belajar IPA

\begin{tabular}{|c|c|c|c|c|c|c|}
\hline $\begin{array}{l}\text { Sumber } \\
\text { Varians }\end{array}$ & JK & & RJK=JK/Db & $\begin{array}{c}\text { F }_{\text {hitung }}= \\
\text { RJK/DK }\end{array}$ & $\frac{\mathbf{F}_{\text {tabel }}}{\alpha=0,05}$ & Keterangan \\
\hline A & 93,09 & 1 & 93,09 & 5,22 & 4,08 & Signifikan \\
\hline $\mathrm{B}$ & 1859 & 1 & 1859 & 104,20 & 4,08 & Signifikan \\
\hline $\mathrm{AB}$ & 626,27 & 1 & 626,27 & 35,10 & 4,08 & Signifikan \\
\hline $\mathrm{AK}$ & 2578,36 & 3 & 859,45 & - & - & - \\
\hline DK & 713,64 & 4 & 17,84 & - & - & - \\
\hline $\mathrm{TR}$ & 3292 & 4 & - & - & - & - \\
\hline
\end{tabular}

Keterangan:

JK : Jumlah Kuadrat Sumber Varians

$\mathrm{Db} \quad$ : Ferajat Bebas Sumber Varians

RJK : Rata-rata Jumlah Kuadrat Sumber Varians

DK : Jumlah Kuadrat Dalam Kelompok

Berdasarkan perhitungan analisis varians (ANAVA) yang ditampilkan pada Tabel 4 di atas dapat dijelaskan sebagai berikut:

Pertama, hasil perhitungan menunjukkan bahwa ${ }_{\text {ung }} \quad=5,22>_{\text {: }} \quad=4,08$ pada $=0,05$, berarti hipotesis nol ditolak. Hal ini berati bahwa terdapat perbedaan yang signifikan antara hasil belajar IPA siswa yang menggunakan model pembelajaran Learning Cycle dengan siswa yang menggunakan model pembelajaran Contextual Teaching and Learning. 'Berdasarkan data diperoleh rata-rata hasil belajar IPA $\left(\mathrm{A}_{1}\right)=$ 
24,45 $>\left(\mathrm{A}_{1}\right)=21,55$ berarti hasil belajar IPA siswa yang menggunakan model Learning Cycle lebih tinggi dibandingkan model Contextual Teaching and Learning.

Kedua, hasil penelitian diperoleh data (Tabel 3) sebagai berikut: (1) pada konsep diri positif, rata-rata hasil belajar IPA siswa yang menggunakan model Learning Cycle $\left(\mathrm{A}_{1} \mathrm{~B}_{1}\right)=34,73$ lebih tinggi dibandingkan model Contextual Teaching and Learning $\left(\mathrm{A}_{2} \mathrm{~B}_{1}\right)=24,27$; dan (2) pada konsep diri negatif, rata-rata hasil belajar IPA siswa yang menggunakan model Learning Cycle $\left(\mathrm{A}_{1} \mathrm{~B}_{2}\right)=14,18$ lebih rendah dibandingkan model Contextual Teaching and Learning $\left(\mathrm{A}_{2} \mathrm{~B}_{2}\right)=18,82$. Sementara hasil perhitungan menunjukkan bahwa $F_{\text {hitung }}=35,10>F_{\text {tabel }}=4,08$ pada $\alpha=0,05$, berarti hipotesis nol ditolak. Hal ini berati bahwa model pembelajaran mempunyai pengaruh yang signifikan terhadap hasil belajar IPA tergantung kepada konsep diri dan sebaliknya.

Selanjutnya dilakukan Uji Tukey, hasil perhitungannya dapat dirangkum pada Tabel 5 berikut ini.

Tabel 5. Rangkuman Hasil Perhitungan Uji Tukey

\begin{tabular}{|c|c|c|c|c|}
\hline No & Kelompok & Qhitung & $\begin{array}{c}Q_{\text {tabel }} \\
\overline{\mathbf{a}}=\mathbf{0 , 0 5}\end{array}$ & Kesimpulan \\
\hline 1 & $\mathrm{~A}_{1}$ dan $\mathrm{A}_{2}$ & 3,22 & 2,95 & $\mathrm{H}_{\mathrm{o}}$ ditolak \\
\hline 2 & $\mathrm{~A}_{1} \mathrm{~B}_{1}$ dan $\mathrm{A}_{2} \mathrm{~B}_{1}$ & 8,21 & 3,11 & $\mathrm{H}_{\mathrm{o}}$ ditolak \\
\hline 3 & $\mathrm{~A}_{1} \mathrm{~B}_{2}$ dan $\mathrm{A}_{2} \mathrm{~B}_{2}$ & 3,64 & 3,11 & $\mathrm{H}_{\mathrm{o}}$ ditolak \\
\hline
\end{tabular}

Ketiga, berdasarkan perhitungan statistik uji Tukey pada Tabel 5 yang

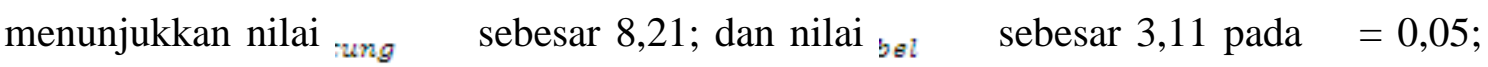
maka tang sel sehingga hipotesis nol ditolak. Hasil penelitian diperoleh data (Tabel 3) bahwa rata-rata hasil belajar IPA siswa yang menggunakan model Learning Cycle $\left(\mathrm{A}_{1} \mathrm{~B}_{1}\right)=34,73$ lebih tinggi dibandingkan dengan rata-rata hasil belajar IPA 
menggunakan model Contextual Teaching and Learning $\left(\mathrm{A}_{2} \mathrm{~B}_{1}\right)=24,27$ pada siswa yang memiliki konsep diri positif.

Keempat, berdasarkan perhitungan statistik uji Tukey pada Tabel 5 yang

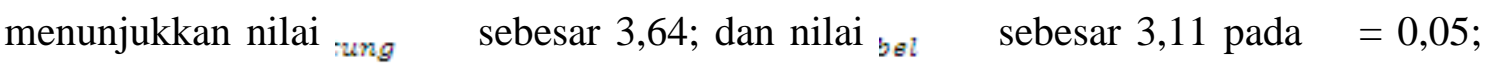
maka sung bel sehingga hipotesis nol ditolak. Hasil penelitian diperoleh data (Tabel 3) bahwa rata-rata hasil belajar IPA siswa yang menggunakan model Learning Cycle $\left(\mathrm{A}_{1} \mathrm{~B}_{2}\right)=14,18$ lebih rendah dibandingkan dengan rata-rata hasil belajar IPA model Contextual Teaching and Learning $\left(\mathrm{A}_{2} \mathrm{~B}_{2}\right)=18,82$ pada siswa yang memiliki konsep diri negatif.

\section{PEMBAHASAN}

Hasil pengujian hipotesis pertama, bahwa hasil belajar IPA siswa yang menggunakan model Learning Cycle lebih baik daripada hasil belajar IPA siswa yang menggunakan model pembelajaran Contextual Teaching and Learning.

Model pembelajaran Learning Cycle cenderung menggunakan pola pembelajaran dengan pendekatan berpikir induktif. Pembelajaran terlebih dahulu dimulai dengan belajar atau mempelajari konsep-konsep, memberikan macam-macam contoh untuk kemudian dicari kesimpulannya. Dari beberapa contoh serta konsep ini siswa lebih memahi konsep materi yang dipelajari untuk kemudian mengambil suatu keputusan yang bersifat umum. Hal ini membantu siswa dalam mengembangkan kemampuan berpikir tingkat tinggi dan kreativitasnya dalam observasi, diskusi, demonstrasi, dan menggeneralisasikannya. Tugas guru adalah menciptakan suasana aktif belajar dengan mendorong siswa mengadakan pengamatan dan 
memfokuskan pengamatan melalui pertanyaan-pertanyaan sehingga siswa lebih aktif dan termotivasi untuk belajar.

Pernyataan di atas menujukkan bahwa pembelajaran model Learning Cycle lebih efektif digunakan dalam pembelajaran. Hal ini didukung dengan hasil penelitian yang dilakukan oleh Sutrisno (2013: 16) dengan judul "Pengaruh Model Learning Cycle 7E terhadap Motivasi Belajar Siswa dalam Pembelajaran Biologi”. Kesimpulan dari penelitian ini bahwa model Learning Cycle 7E berpengaruh nyata terhadap motivasi belajar siswa kelas XI SMA Negeri 1 Banyudono tahun 2011/2012.

Model pembelajaran Contextual Teaching and Learning, pola pembelajaran melalui pendekatan berpikir deduktif, kebalikan dari induktif. Pembelajaran diawali dengan sajian model atau sebuah konsep, kemudian untuk dijelaskan bagian-bagiannya. Hal ini keterampilan berpikir siswa lebih ditentukan oleh tingkat pengetahuan awal yang dimilkinya. Siswa yang memiliki pengetahuan awal rendah, serta pengalaman siswa yang terbatas pada hal-hal yang mereka ketahui saja, maka model Contextual Teaching and Learning ini terasa kurang sesuai, menjadikan motivasi belajar yang timbul pada diri siswa menjadi rendah, proses pemberian materi menjadi lambat serta membutuhkan waktu yang lama untuk menjelaskan materi. Sehingga guru lebih aktif daripada siswanya karena pembelajaran yang dilakukan guru lebih banyak dengan memberi penjelasan. Implikasinya bahwa pemberian kesempatan siswa untuk mengeksplor lingkungan, mengembangkan konsep, serta menghubungkan konsepkonsep baru dengan menggunakan atau memperluas konsep yang dimiliki untuk menjelaskan suatu fenomena yang baru atau berbeda. Sehingga siswa dapat belajar secara aktif mempelajari materi dengan bekerja dan berpikir. Pengetahuan dikonstruksi sendiri oleh siswa dengan mengaitkan informasi baru yang diperoleh melalui 
penyelidikan dengan pengalaman mereka yang miliki. Dengan demikian penerapan model ini dapat meningkatkan motivasi belajar sekaligus dapat mengembangkan sikap ilmiah siswa sehingga hasil belajar IPA dapat tercapai secara optimal.

Pengujian hipotesis kedua, bahwa hasil belajar IPA yang saling dipengaruhi oleh model pembelajaran dan konsep diri menunjukkan adanya atau terdapat pengaruh interaksi.

Hasil penelitian ini selanjutnya menunjukkan bahwa model pembelajaran dan konsep diri siswa sangat mempengaruhi dan turut menentukan keberhasilan siswa dalam memperoleh hasil belajar IPA yang lebih baik. Adanya pengaruh interaksi ini membuktikan bahwa masing-masing model pembelajaran akan memberikan pengaruh yang berbeda terhadap hasil belajar IPA jika diperlakukan pada kelompok siswa yang memiliki tingkat konsep diri yang berbeda pula. Tingkat perlakuan yang dimaksud adalah: (1) untuk mencapai hasil belajar IPA yang optimal, lebih baik menggunakan pembelajaran model Learning Cycle terutama pada kelompok siswa yang memiliki konsep diri positif; (2) pada kelompok siswa yang memiliki konsep diri negatif, pembelajaran dengan menggunakan model pembelajaran Learning Cycle tidak berpengaruh, karena pada konsep diri negatif lebih baik menggunakan model pembelajaran Contextual Teaching and Learning.

Hasil analisis data tersebut di atas memberikan gambaran bahwa pada model pembelajaran Learning Cycle, konsep diri positif mampu memberi efek kontribusi terhadap peningkatan hasil belajar IPA. Efek ini disebabkan oleh konsep diri siswa secara positif memandang dirinya yang meyakini bahwa dirinya sebagai orang yang memiliki kemampuan fisik, psikologis serta pengetahuan akademis yang baik. Pada model Contextual Teaching and Learning dengan konsep diri negatif mampu memberi 
efek kontribusi terhadap peningkatan hasil belajar IPA. siswa lebih banyak menggunakan kemampuan pengalaman dan pengetahuan yang dimilikinya.

Penjelasan di atas mengungkapkan bahwa konsep diri pada diri siswa merupakan bagian dari kemampuan rasa percaya diri siswa saat proses pembelajaran, maka akan mempengaruhi prestasi atau hasil belajarnya. Hal ini didukung teori tentang konsep diri, dikatakan bahwa orang yang akan menilai dirinya secara positif, dan dalam menjalani kehidupannya akan memiliki keyakinan diri dan penuh keoptimisan (Surna, 2014: 13). Implikasinya bahwa prestasi akademik siswa ditentukan oleh model pembelajaran yang sesuai dengan konsep diri yang dimilikinya. Dalam hal ini guru harus mampu memilih model pembelajaran yang sesuai dengan konsep diri yang dimiliki siswa. Hal ini menuntut guru tersebut harus bisa memperluas wawasannya terutama dalam mempelajari serta mengaplikasikan model-model pembelajaran. yang sesuai dengan karakteristik siswa. Guru lebih kreatif dalam merancang kegiatan pembelajaran yang menarik dan inovatif sesuai karakteristik siswa dan mampu mengakomodir semua karakteristik siswa sehingga pembelajaran di kelas lebih efektif dan hasil belajar siswa dapat optimal.

Hasil pengujian hipotesis ketiga, memberikan makna bahwa siswa yang memiliki konsep diri positif yang menggunakan model pembelajaran Learning Cycle menjadi lebih baik dalam belajar atau mempelajari mata pelajaran IPA daripada model Contextual Teaching and Learning.

Hal lain yang mempengaruhi pencapaian hasil belajar IPA pada siswa yang memiliki konsep diri positif bahwa pembelajaran dengan model Learning Cycle adalah kesiapan mereka untuk meningkatkan kemampuan, optimis, rasional serta mempunyai rasa tanggung jawab dalam menerima materi pembelajaran serta menghadapi tugas- 
tugas yang diberikan dengan baik sehingga pencapaian hasil belajar IPA yang lebih baik dapat tercapai.

Sebaliknya, pada model Contextual Teaching and Learning tidak diketemukan fase pembelajaran atau tahapan belajar seperti pada model Learning Cycle. Karena pembelajaran Contextual Teaching and Learning lebih menekankan pada indikator dan prinsip pembelajaran yang berdasarkan pada konteksnya dalam kehidupan nyata siswa, lebih menenekankan pada kemampuan sofskill. Di awal pembelajaran, materi pelajaran diberikan model sebuah konsep secara terdefinisi (modelling) yang selanjutnya akan dipelajari bagian-bagiannya. Siswa belajar dalam bentuk kelompok (learning community) masing-masing kelmpok mempelajari bagaian-baian yang berbeda, sehingga pada akhir pembelajaran seluruh kelompok memperoleh pengetahuan secara sharing melalui kelompok lain. Kesempatan siswa untuk diskusi, bertanya, observasi hanya sebatas kemampuan pada hal-hal yang mereka ketahui saja, sehingga kesempatan untuk berfikir dan memberi keputusan secara utuh terbatas. Pendekatan ini, mudah diterapkan manakala siswa sudah memiliki pengetahuan awal yang sudah baik serta ditunjang dengan kesiapan mental dan rasa percaya diri atau keyakinan yang positif atas keberhasilan belajarnya, namun sebaliknya bahwa pendekatan ini sulit atau kurang sesuai jika diterapkan pada siswa yang memiliki konsep diri negatif, karena siswa selalu berpandangan dan meyakini dirinya sebagai orang yang kurang mampu secara akademis sehingga siswa terebut cenderung bersikap masa bodoh, acuh tak acuh terhadap pelajaran yang akhirnya prestasi atau hasil belajar tidak tercapai secara optimal.

Hasil pengujian hipotesis didukung oleh hasil penelitian dengan judul "The Sequence of Learning Cycle Activities in High School Chemistry” (Abraham, 1986: 3136). Hasil penelitian mereka menunjukkan bahwa tahapan pada kegiatan model siklus 
belajar memberikan kontribusi terhadap hasil belajar Kimia di SMA. Dengan kata lain bahwa model pembelajaran Learning Cycle dapat meningkatkan hasil belajar Kimia siswa terutama pada siswa yang memiliki konsep dirinya secara positif. Implikasinya bahwa pencapaian prestasi akademik menjadi baik maka guru dapat menyesuaikan antara model pembelajaran dengan konsep diri yang dimiliki siswa. Khususnya guru IPA mampu mengakomodir kelebihan dan kekurangan yang ada pada diri siswa, sehingga model pembelajaran yang digunakan guru mengajar sesuai dengan kebutuhan dan kondisi siswa, dan akhirnya tercapai hasil belajar yang optimal.

Hipotesis keempat, bahwa bagi siswa yang belajar menggunakan model Contextual Teaching and Learning dan memiliki konsep dirinya secara negatif, maka hasil belajarnya dapat dicapai secara optimal daripada menggunakan model Learning Cycle.

Secara teori manakala siswa memiliki konsep diri negatif maka ia akan meyakini dirinya sebagai orang yang berkepribadian buruk sehingga siswa tersebut cenderung bertingkah laku kurang baik karena pandangan dan keyakinan atas dirinya juga rendah. Hal ini menyebabkan keterampilan berpikir siswa menjadi lemah. Untuk menjelaskan suatu konsep, serta menghubungkan konsep menjadi suatu pemahaman yang baru kurang baik meskipun bisa dilakukan tetapi dalam proses berfikirnya menjadi lambat. Membuat mereka sulit untuk mengolah konsep pengetahuan yang mereka peroleh untuk menjadi suatu pengetahuan baru dalam hal kemampuan menelaah, menalar yang tidak maksimal. Pernyataan tersebut didukung dengan teori yang disampaikan oleh Bandura (1999: 11) bahwa seseorang dengan tingkat kemampuan keberhasilan yang rendah ditandai dengan aspirasi dan komitmen yang lemah sehingga akan menghindar dari tugas-tugas yang sulit. 
Selanjutnya, model Contextual Teaching and Learning dalam pembelajarannya lebih mengarah pada pendekatan belajar secara deduktif, yaitu materi diolah dari yang umum atau rumusan konsep dalam bentuk model (modelling) untuk kemudian dijelaskan setiap bagian-bagiannya. Dalam proses ini guru lebih berperan secara aktif karena di awal pembelajaran guru terlebih dahulu harus memberikan penjelasan materi pelajaran secara jelas dengan memperlihatkan bentuk atau rumusan konsep secara modelling, sehingga materi belajar akan lebih mudah dipahami dan diingat oleh setiap siswa dalam pembelajaran. Strategi dengan pendekatan berpikir deduktif ini lebih banyak digunakan penerapannya pada pembelajaran model Contextual Teaching and Learning. dan lebih mudah diterapkan pada siswa yang memiliki konsep diri negatif. Oleh karenanya dengan pendekatan berpikir secara deduktif guru lebih banyak waktu untuk menjelaskan, memerlukan bimbingan guru sehingga belajar siswa termotivasi dengan baik, membuat siswa lebih nyaman belajarnya, siswa lebih berani dan lebih aktif, serta kemampuan dalam memberi kesimpulan pun semakin baik mudah untuk dipahami, dan hasil belajar siswa dapat tercapai secara optimal. Implikasinya bagi siswa yang memiliki konsep diri negatif, dengan strategi pembelajarannya diawali dengan bentuk konsep yang utuh melalui pemodelan materi (modelling) yang menjadi acuan tujuan pembelajaran yang akan dicapai maka pada siswa yang memiliki konsep diri negatif, dengan pemodelan ini memori atau kemampuan mengingat materi menjadi lebih baik, dan hal ini akan memperkuat konsep diri mereka yang baik. Melalui konsep diri positif tentang dirinya berarti pandangan mereka semakin positif, sehingga dalam diri siswa timbul keyakinan bahwa apa yang ia pikirkan dan rasakan tentang prestasi belajarnya dapat tercapai dengan baik. 
Keterbatasan dalam penelitian ini pengendalian atau kontrol terhadap variabel bebas di luar variabel yang diteliti dilakukan secara ketat. Bahwa pelaksanaan peneltian ini dilakukan selama proses pembelajaran di kelas, maka pelaksanaan eksperimen perlu menyesuaikan waktu dan jadwal dengan pembelajaran di kelas tersebut. Pengaruh interaksi subjek peneltian antara kelas kontrol dan kelas eksperimen dalam pembelajaran IPA. Bahwa untuk menyelesaikan kompetensi dasar pembelajaran IPA kelas VIII semester gasal pada saat penelitian, dilaksanakan dalam waktu yang singkat yaitu selama delapan kali pertemuan. Maka selama melaksanakan pembelajaran tersebut, interaksi yang terjadi kemungkinan bukan hasil murni. Penelitian ini dilakukan pada jumlah sampel yang relatif kecil, yaitu 44 siswa yang terbagi dalam empat kelompok. Memperhatikan kondisi seperti ini maka penggeneralisasian hasil penelitian hanya berlaku pada sekolah tempat penelitian dilakukan, yaitu di SMP Neger 24 Bandar Lampung, maka kekuatan statistik yang diperoleh untuk mendukung kesimpulan kemungkinan saja lemah. Oleh karena itu signifikansi hasil uji statistik yang diperoleh perlu diuji lebih lanjut. Instrumen yang digunakan pada penelitian ini sepenuhnya hasil pengembangan awal peneliti, belum menjadi instrumen baku. Meskipun demikian prosedur pengembangan instrumen standar telah dilakukan mulai dari pengkajian teori, pemaknaan konstruk ke dalam dimensi dan indikator, mengembangkan instrumen penelitian, melakukan uji coba, menguji validitas dan reliabilitas butir, sampai merevisi dan mengkonstruksinya menjadi alat pengumpul data dalam penelitian yang sebenarnya. Selanjutnya, hasil pengukuran yang dicapai instrumen pengumpul data pada penelitian ini ada kemungkinan belum sepenuhnya menggambarkan atribut yang sebenarnya ada.

\section{KESIMPULAN}


1. Terdapat perbedaan hasil belajar IPA antara siswa yang menggunakan model pembelajaran Learning Cycle dengan siswa yang menggunakan model pembelajaran Contextual Teaching and Learning. Hal ini berarti bahwa secara keseluruhan penggunaan model pembelajaran Learning Cycle berpengaruh terhadap hasil belajar IPA siswa.

2. Terdapat interaksi antara model pembelajaran (model Learning Cycle dan model Contextual Teaching and Learning) dengan konsep diri (konsep diri positif dan konsep diri negatif) terhadap hasil belajar IPA. Hal ini berarti bahwa penggunaan model pembelajaran yang berbeda berpengaruh terhadap hasil belajar IPA siswa yang memiliki konsep diri yang berbeda pula.

3. Terdapat perbedaan hasil belajar IPA antara siswa yang menggunakan model pembelajaran Learning Cycle dengan siswa yang menggunakan model pembelajaran Contextual Teaching and Learning pada siswa yang memiliki konsep diri positif. Hal ini berarti bahwa pada siswa yang memiliki konsep diri positif dengan penggunaan model pembelajaran Learning Cycle berpengaruh terhadap hasil belajar IPA.

4. Terdapat perbedaan hasil belajar IPA antara siswa yang menggunakan model pembelajaran Learning Cycle dengan siswa yang menggunakan model pembelajaran Contextual Teaching and Learning pada siswa yang memiliki konsep diri negatif. Hal ini berarti bahwa pada siswa yang memiliki konsep diri negatif dengan penggunaan model pembelajaran Contextual Teaching and Learning berpengaruh terhadap hasil belajar 


\section{DAFTAR PUSTAKA}

Abraham, M.R. dan Renner J.W., "The Sequence of Learning Cycle Activities in High School Chemistry", Journal of Research in Science Teaching, 23 (2), 1986.

Bandura, Albert. Self Efficay in Changing Societies. New York: Cambridge University Press, 1999.

BSNP. Standar Isi, Standar Kompetensi dan Kompetensi Dasar SMP/MTs. Jakarta: BSNP, 2006.

Carin, Arthur A.,Teaching Modern Science, 7 th ed. New York: Macmillan Publishing Company, 2001.

Johnson, Elaine B. Contextual Teaching and Learning Menjadikan Kegiatan Belajar Mengajar Mengasyikkan dan Bermakna. terjemahan Bandung: Mizan Media Utama (MMU), 2009.

Murwani, Santosa. Statistika Terapan: Teknik Analisa Data. Jakarta: Program Pascasarjana UNJ. 2005.

Naga, Dali Santun. Probabilitas dan Skor pada Hipotesis Statistika. Jakarta: UPT Penerbitan Universitas Tarumanegara, 2008.

Surna, I Nyoman dan Olga D. Pandeirot, Psikologi Pendidikan 1. Jakarta: Erlangga, 2014.

Sutrisno, Wawan, Sri Dwiastuti, dan Puguh Karyanto. "Pengaruh Model Learning Cycle terhadap Motivasi Belajar Siswa dalam Pembelajaran Biologi”, Jurnal Universitas Negeri Surakarta, Vol.11 (2) Edisi Khusus September, 2013 